THE INFLUENCE OF INITIATORS ON SUPPLY CHAIN VALUE CREATION

\author{
Jayanth Jayaram* \\ University of South Carolina \\ Moore School of Business \\ Department of Management Science \\ University of South Carolina \\ 1705 College Street \\ Columbia, SC 29208 \\ jayaram@moore.sc.edu \\ Vijay R. Kannan \\ Department of Business Administration \\ College of Business \\ Utah State University \\ Logan, UT 84322-3510 \\ Tel/Fax: (435) 797-7212/2634 \\ v.kannan@usu.edu \\ Keah Choon Tan \\ University of Nevada Las Vegas \\ College of Business \\ Department of Management \\ 4505 Maryland Parkway, Box 456009 \\ Las Vegas, NV 89154-6009 \\ Tel: (702) 895-3873 \\ kctan@unlv.nevada.edu
}

April 14, 2004

[Final accepted version to IJPR]

* Corresponding author. 


\title{
THE INFLUENCE OF INITIATORS ON SUPPLY CHAIN VALUE CREATION
}

\begin{abstract}
Value creation in the supply chain has attracted considerable attention in the literature. It has typically been characterized as being the result of either external or organization spanning, or internal efforts to improve supply chain performance. Few studies have examined the simultaneous effects of internally and externally focused efforts to improve supply chain performance. Moreover, there is no discussion in the literature of the precursors or initial conditions that lead to successful supply chains. Drawing from different theoretical perspectives, we identify two key motivators or initiators of value creation in supply chains: structural mechanisms and relationship building. We propose that these initiators have a positive influence on value creation efforts, operationalized by the improvement of supply processes and responsiveness to customer needs (external focus), and internal production processes (internal focus). A structural equation model linking initiators and value creation mechanisms to performance is proposed and tested using data from a large sample of firms. Results of the study suggest that firms that pay attention to initiators may derive greater benefit from their value creation efforts and thus yield improved performance.
\end{abstract}

Subject Areas: Empirical Research, Supply Chain Management, Structural Equation Modeling 


\section{Introduction}

Despite the widely cited advantages of supply chain management (SCM), few companies have in practice excelled in supply chain integration. There are several possible reasons for this. First, managing cross-functional linkages has proved to be harder than anticipated (Powers et al. 1988; Rho et al. 1994). In particular, joint consideration of the potential effects of decisions that span functional boundaries remains a thorny issue for most companies. The classic trade-off between marketing and operations priorities provides a vivid illustration of the dilemma (Reukert \& Walker 1987). While the marketing function typically seeks a wide variety of products and the ensuing advantages of differentiation, the operations function seeks product and process standardization and stability, with particular attention paid to corresponding cost reduction goals. Another example is the interface between research and development (R\&D) and marketing. Despite the often-cited practice of using integrated product development teams comprising participants from several functional areas, key decisions can create a 'pull versus push' tension (Moenaert et al. 1994; Song et al. 1996). The marketing function attempts to 'pull' product features collected through the customer feedback process into the final product design, while simultaneously, the R\&D function, in an effort to show off their latest technology wares, may 'push' the latest technical features into the final product design.

A second reason is that managing boundary spanning linkages is even harder than managing intra-firm, cross-functional interfaces. For example, few companies have been successful in involving suppliers in their own strategic decisions (Dyer et al. 1998; Handfield et al. 2000; Lamming 1993; Turnbull et al. 1992). One reason for this is past institutional problems associated with arms-length relationships between suppliers and the firm. Another is the confusing and changing objectives firms have with respect to their suppliers. Relationships 
between original equipment manufacturers (OEMs) and first tier auto suppliers provide a good example of this problem. OEMs had to shake off a history of arms length relationships with their suppliers before they could change their operating paradigm to one with a more strategic orientation towards the supply base. The main reason for not involving suppliers in a firm's strategic decisions was the fear among OEMs of opportunistic behavior by suppliers. Many first tier suppliers conducted business with other OEMs leading to possible conflicts of interest. Over-reliance on cost as the primary basis for the selection, retention and evaluation of suppliers, also impeded the transition from arms-length to strategic supplier relationships.

If only a few firms have been successful in involving suppliers in their strategic decisions, fewer still have been successful in doing the same with customers. When Dell Computers was implementing its 'direct model' to institutional buyers, problems arose regarding integration with the purchasing systems of key customers such as Proctor and Gamble, and Detroit Edison (Wagner 2000). Lack of communication between functions closest to the customer (i.e., customer service and marketing) and the rest of the organization, can also lead to problems in customer integration (Lawrence 2000). Fawcett and Magnan (2001) found that functions closer to the end customer, for example logistics and customer service, placed greater importance on supply chain integration and enjoyed higher levels of integration than functions further from the customer such as purchasing. The implementation of formal customer involvement programs, such as customer relationship management (CRM) is another area in which this problem is commonly seen. Environmental conditions, specifically volatility and variety in customer demand patterns, have also been a contributing factor. Consistent with the classic arguments of Hill (1994), the customer end of the business has moved faster than the operations function can cope with (Hausman et al. 2002). The coping mechanism required, a flexible and agile operating 
infrastructure, has proved to be unattainable for most firms. The lack of simple tools for communicating product design features throughout the organization has also hindered efforts to integrate customers into the decision making process (Govers 2001; Martins \& Aspinwall 2001). For example, the commonly cited 'House of Quality' (Hauser \& Clausing 1987) has been too hard and time-consuming for most firms to implement successfully.

A third reason for the failure of firms to excel in managing supply chains is that they have not paid adequate attention to structural issues such as the design of supply chains involving both boundary spanning and cross functional linkages. Fisher (1997) argued that firms inadvertently fall into the trap of mismatching desired supply chain objectives with the product being delivered. The mismatch can occur when firms configure their supply chains for efficiency when products are more consistent with a dynamic, variety driven environment, or when firms deploy a responsive supply chain for functional, commodity type products.

While the pattern of inconsistent results stemming from supply chain management strategies is characteristic of the experiences of the average firm, this is not the case for so-called exemplars of supply chain management. In-depth scrutiny of these firms reveals trends and practices beyond the value creation processes themselves (Drickhamer 2001). These take the form of what we term 'initiators', governance mechanisms that are necessary precursors to value creation. Two types of initiators are reported in the literature - structural mechanisms and behavioral mechanisms. Structural mechanisms reflect the need to select the right supply chain members, locate close to them, and make sure that there is a fit between the capabilities of the firm and its supply chain partners (Cheng 1983; Prescott 1999). Behavioral mechanisms reflect the development of relationships with supply chain partners. This involves, for example, the establishment of mutual trust, the sharing of key information between suppliers and buyers, and 
the commitment of suppliers to supporting their buyer's strategic objectives (Dyer \& Singh 1998; Handfield \& Bechtel 2002).

Our contention is that leading edge supply chain management companies like Intel, Proctor and Gamble, Hewlett Packard and Wal-mart, have been successful in managing their supply chains because they have paid appropriate attention to supply chain initiators. Wal-mart provides a good illustration of a firm that has paid attention to structural mechanisms. Key supply chain members such as Proctor and Gamble on the supply side and J.B. Hunt on the distribution side have chosen to locate close to Wal-mart's headquarters in Bentonville, Arkansas. Brown et al. (1999) found in a study of 433 wholesaler-supplier relationships that firms that were both closely linked and flexible with their supply chain partners paid careful attention to behavioral issues such as perceptions of fairness and the use of informal (as opposed to formal) contracts. They found that wholesalers were more satisfied with supplier relationships when informal contracts were used, and they perceived decisions made by other channel members to be just and fair. Firms that used informal contracts also had fewer conflicts among supply chain partners. In contrast, there was greater conflict when formal contracts were used among supply chain partners. In an empirical study of purchasing managers in North American manufacturing firms, Handfield and Bechtel (2002) found that efforts by the buying firm to build trust resulted in more responsive behavior by suppliers even when buyers had no power over suppliers.

The argument presented in this study is that recognition of the need to manage both crossfunctional and boundary spanning relationships enables companies that excel in supply chain management to realize performance benefits. In particular, exemplars of supply chain management have paid careful attention to structural mechanisms and behavioral mechanisms prior to managing value creation processes internally and across organizational boundaries. The 
remainder of the paper is organized as follows. The following section summarizes the relevant literature that provides the theoretical support for our research model and hypotheses. After presenting the model and hypotheses we describe the methodology used to test the model. We conclude by discussing the implications of the results in the context of the theory and practice of supply chain management and offer suggestions for future research.

\section{Theoretical Justification}

Existing theory is used to support two main themes: 1) effective cross functional and boundary spanning value creation efforts lead to firm performance benefits; and 2) these efforts are dependent on structural and behavioral mechanisms. A summary of prior work consistent with these themes is presented in Table 1. Two theories help to explain why some firms are more successful than others in translating integration efforts into improved performance. Transaction cost economics theory explains why firms choose internal structures to accomplish goals as opposed to alternative governance structures such as the market or contracts (Coase 1937; Williamson 1975; Wernerfelt 1984). The underlying basis of the theory is that the relative costs of using markets as opposed to employing firm controlled resources drives resource allocation decisions. However, the theory also provides a framework for analyzing the efficiency of interorganizational boundary spanning decisions (McWilliams \& Gray 1995; Poppo \& Zenger 1998; Tsang 2000). In particular, it argues that firms realize efficiencies, typically related to cost, when there is congruence between a firm's governance structure and attributes of the underlying transactions (Williamson 19811985 1991). For example, firms that vertically integrate to minimize costs, do so to safeguard transaction specific investments and to adapt to environmental uncertainty associated with transactions (Heide \& John 1988 1990; Rindfleisch 1997). The implication is that for these firms, internal and cross-functional integration are vital. 
In contrast, firms relying on market mechanisms such as outsourcing will be more concerned with boundary spanning integration.

\section{Insert Table 1 about here}

Some researchers have argued that firms integrate more when there is a need for frequent adjustments with market mechanisms which can be implemented at lower cost (Wernerfelt 1997; Simester \& Knez 2002). Others however caution against over-reliance on transaction cost economics theory without adequate consideration of the firm's competencies and ability to coordinate strategic resources that are not transaction specific (McWilliams \& Gray 1995; Poppo \& Zenger 1998; Tsang 2000). They suggest that resource-based theory provides a better means of evaluating the success or failure of boundary spanning and cross-functional integration efforts. Barney (1991) argued that competitive advantage emanates from the acquisition and exploitation of valuable and inimitable resources. Proponents of resource-based theory thus suggest that decisions regarding how boundary spanning integration should occur be made on the basis of whether external entities, as opposed to the firm, have unique resources that could be a source of competitive advantage (McWilliams \& Gray 1995; Poppo \& Zenger 1998). Accordingly, transaction and management costs are dependent on heterogeneous capabilities and firm resources (Barney 1991; Poppo \& Zenger 1998; Tsang 2000). In an empirical study of 113 firms, Rasheed and Geiger (2001) found that a firm's resources had a significant effect on decisions to outsource or internalize value chain functions. They found that firms constantly seek new modes of value creation in a supply chain. However, managers typically lack a framework for determining the optimal value chain configuration given their particular internal and external 
circumstances (Fisher 1997; Janssen \& Sol 2000). In other words, outsourcing decisions require both an evaluation of transaction costs and consideration of the locus of core capabilities.

Two disparate sets of theories help to explain how structural and behavioral mechanisms can lead to successful integration efforts. The first provides support for the concept of structural mechanisms and draws upon key works in organization theory, reengineering, and Just in Time/Lean Manufacturing. Chandler (1962) argued that the design and control of appropriate organizational structures has a positive influence on the effectiveness of strategy, which in turn leads to higher levels of performance. Research on just in time (JIT) systems and lean manufacturing (Schonberger 1982; Womack et al. 1990) identify the notion of value added in systems, pointing out that most systems contain waste, which, if eliminated, can lead to higher performing systems. This emphasis on value-added and specifically on processes as the building blocks of value is also a key element of the work on reengineering by Hammer and Champy (1993). Taken together, the cited works suggest the need for firms to look at structural characteristics of systems, and to critically evaluate the sources of value-added in their operations. As a corollary, this suggests that the effectiveness of technological or strategic interventions can be compromised if not preceded by careful examination of structural characteristics such as the proximity and commitment of supply chain partners.

The second set of theories provides support for the notion that behavioral mechanisms have an impact on the success of value creation efforts. Drawing on the sociology literature, the boundary spanning view of attachment (D’Aveni 1978; Granovetter 1985) suggests that social themes bind and align inter-organizational linkages. Linkages that explicitly or implicitly agree on common bases or attachments are more likely to result in enduring relationships and cooperation compared to linkages devoid of common bases of attachment. Cyert and March 
(1963) argued that organizations can be characterized as a social network comprised of actors. It is the behavior of these actors that typifies motives for decision-making in organizations. This is consistent with the organized behavior system espoused by Alderson (1965). He argued that interactions within an organized behavior system, such as a marketing channel, are strong when channel participants are willing to accept substantial costs and risks to ensure the survival of remaining channel members.

The behavioral view represented a distinct departure from the inanimate or detached view of organizations that prevailed at the time. A logical consequence of these themes was that ideas regarding relationship building began to evolve in the strategy and marketing literature (Heide 1994; Kumar 1996; Morgan \& Hunt 1994). Fundamental to this school of thought were notions of trust and commitment. Attempts at inter-organizational integration without first developing trust among channel entities were considered likely to fail. As trust gradually developed, channel entities could be expected to commit to the joint pursuit of goals and objectives.

The supporting themes elicited from past theoretical works provide support for the two main objectives of this research. A related objective that has been the focus of considerable attention in previous research is the nexus between internal and external sources of value creation. Heide and John (1988) reported that firms using contract manufacturers enjoyed higher levels of performance when these agents dedicated assets to specific manufacturers. Poppo and Zenger (1998) found that the decision to integrate internally when information services were firm specific was more often made as a result of dissatisfaction with using market governance or outsourcing than due to satisfaction with using internal governance or internal integration. It thus appears that a key explanation for boundary spanning choices stems from the fact that markets lack effective mechanisms for resolving coordination problems, particularly in the absence of 
asset specificity, i.e., dedication of assets by one or more firms in the dyad. Limited evidence also exists regarding the impact of supply chain integration on performance. Defining integration in terms of attributes such as shared ownership of schedules, integration of information systems, and visibility and dissemination of information, Armistead and Mapes (1993) found empirical support for the hypothesis that improved manufacturing performance is associated with a higher degree of supply chain integration.

\section{Research Model and Hypotheses}

While scattered empirical evidence suggests a positive link between efforts to create value in the supply chain and performance for companies at the leading edge of supply chain integration, few studies have identified the drivers that enable these companies to enjoy such benefits. We address this gap in the literature by identifying two such drivers or initiators. Initiators are governance mechanisms that precede specific efforts at value creation in the supply chain. The proposition being made is that leading edge supply chain management companies enjoy the advantages associated with successful integration of value creation efforts due to their recognition of key governance mechanisms. We argue that structural and behavioral mechanisms impact efforts to create sustainable value within the supply chain. Moreover, we argue that value creation and sustainability depend heavily on establishing these key governance mechanisms upfront. Firms should ensure that structural elements such as having an integrated information system, and behavioral relationship building elements such as trust and commitment, are in place prior to embarking on value creation efforts. These sources of governance in turn influence the choice of value creation mechanisms. The specific modes we examine are supplier value (SV), customer value (CV) and internal process value (IPV). Consistent with the rent seeking perspective of firms, the specific choice of integration mechanisms is governed by the motive of 
superior value generation (Black \& Boal 1994). Superior value, in turn, leads to higher performance. These relationships are summarized in Figure 1.

\section{Insert Figure 1 about here}

\subsection{Operationalization of Supply Chain Value Creation - Theoretical Impasse and Resolution}

Limited prior research has addressed the ordering among value creation mechanisms. Morash and Clinton (1998) studied supply chain integration patterns in a large sample of firms representing manufacturers, wholesalers and retailers in the United States, Japan, Korea and Australia. The results of the study pointed to the importance of collaborative closeness and operational excellence as determinants of customer value. Both cross-functional and boundary spanning (i.e., customers and suppliers) collaboration were used to operationalize collaborative closeness. Frohlich and Westbrook (2001) observed that boundary spanning integration, operationalized as supplier integration and customer integration, influence performance. Specifically, they found that firms with high levels of both supplier and customer integration reported higher levels of performance compared to firms that had low levels of either. They also reported that most firms typically integrate either internally or across one source of external integration, i.e., supplier or customer.

Fawcett and Magnan (2001) studied integration patterns of fifty two firms selected for their reputation for progressive supply chain practices. The firms included retailers and finished goods assemblers as well as first and lower tier suppliers. Using in-depth interviews of key executives in these firms, they found that the firms engaged in four primary types of integration; internal, cross functional process integration, backward integration with key first-tier suppliers, forward integration with key first tier customers, and complete forward and backward integration 
with lower tier suppliers and customers. They noted that of the four types of integration, complete forward and backward integration with lower tier suppliers or customers was the least common, with few companies reporting successes across the extended supply chain. The study also indicated that while most firms were fairly advanced in their internal integration efforts, they were only in the early stages of external integration. Moreover, firms were slightly ahead in their forward (customer) integration efforts, suggesting that customer integration was the starting point of external integration in these firms. The study used comparisons of mean scores for the four types of integration to indicate relative ordering among integration mechanisms. The observed pattern of customer integration driving supplier integration and internal process integration thus provides preliminary evidence of ordering among integration mechanisms.

As is evident from the cited literature, there is no agreement as to whether firms should first pursue internally or externally focused efforts to create value in the supply chain. The school of thought that relies on quality function deployment tends to be biased towards starting with the customer (Hauser \& Clausing 1987; Govers 2001; Martins \& Aspinwall 2001). This is based on the premise that customers define the standards for value identification and creation. Discerning of value on an ongoing basis can only be done through the seamless integration of customer perspectives with the firm. Having defined standards of value from the customer viewpoint, the achievement of value creation depends on how effective the elements of value are transmitted to suppliers and internal organizational units. On the other hand, the reengineering school of thought suggests that internally focused efforts are the primary vehicle for operational excellence within a firm (Hammer and Champy 1990; Morash and Clinton 1998). Other studies, while silent on the ordering aspect, have focused on one portion of the supply chain such as logistics (e.g., Pfohl and Mayer, 1999) or have examined differences based on the type of product (e.g., Ramdas 
and Spekman, 2000; Fisher, 1997). Given the lack of theoretical guidelines as to the ordering between supplier, customer, and internal process management, we propose a simple second order factor called supply chain value creation that includes the three individual sources of value, supplier, customer, and internal process, as sub-dimensions. This approach is similar to the operationalization of strategic purchasing competence reported in Narasimhan, Jayaram and Carter (2001). Consistent with the exploratory nature of operationalization of the supply chain value construct, we suggest the following proposition:

Proposition 1: Supply chain value creation is a multi-faceted construct that can be captured in terms of the three sub-dimensions, supplier value, customer value, and internal process value.

We test this proposition using rigorous structural equation modeling techniques to be described in a later section, and report on the robustness of this construct. Because of the tentative nature of this measurement of the supply chain value construct, only the operationalization is labeled as a proposition. In the next section, we use extant theory to develop the research hypotheses as laid out in Figure 1.

\subsection{Research Hypotheses}

Two themes guide the setting of the research hypotheses. First, structural mechanisms and relationship building influence supply chain value chain creation. Second, higher levels of supply chain value creation are associated with higher levels of performance.

\subsubsection{Structural Mechanisms and Value Chain Integration}

A blended theoretical view of transaction costs and the locus of core capabilities suggested by the resource-based view of the firm provide support for structural initiators as an important enabler of value creation. Chandler (1962), in his classic treatise on structure posited 
that the design and control of appropriate structures has a positive influence on value creation, which in turn leads to higher levels of performance. More recent works by Hammer and Champy (1993), Schonberger (1982), and Womack et al. (1990), also suggest the importance of structural elements as the driving force of high performing systems. Bartholomew (1999) cited several examples of companies that deployed common information systems to facilitate integration among members of supply chains. For example, the RosettaNet consortium has attempted to address the issue of diverse software programs, communications protocols, and data standards that plague efforts of integration in the supply chains of firms in the computer industry. Through the use of a common information systems platform, this consortium has been able to integrate business processes that span computer manufacturers, software companies, distributors, resellers, systems integrators, and volume end users effectively.

Visibility of inventories across the supply chains also enhances value creation. Firms in rapidly changing industries such as the semiconductor and contract manufacturing industries have felt the need to understand how changes in pipeline inventories affect the entire supply chain. For example, the ability to locate component shortages or excess inventory in real time and to use the information to respond quickly requires coordination among supply chain partners. Improving the visibility of customers' changing demand patterns reduces overproduction and improves allocation of supply to contract manufacturers. Cisco Systems, a large buyer of semiconductors, was forced to write off $\$ 2.5$ billion in inventory purchased based on overly optimistic demand forecasts (Peterson 2002). In response, the company invested in an information system that provides real time status of inventory levels of its upstream (semiconductor manufacturers) and downstream (customers for products such as routers) supply chain partners. 
Finally, the willingness of suppliers and customers to participate in the firm's supply chain efforts is critical. Typically, such participation and cooperation among supply chain partners entails mutual commitment. An example of such commitment is the early order commitments of Wal-Mart to Warner-Lambert to supply Listerine, a popular brand of oral cleaning liquid (Koloszyc 1998). Wal-Mart agreed to extend its order cycle from nine days to six weeks to match the manufacturing time for Listerine, and to share the ensuing risks. Recent empirical research has also found that early order commitments by suppliers can enhance supply chain coordination and reduce system wide inefficiency (Gilbert \& Ballou 1999; Zhao et al. 2002). In summary, these works suggest that structural characteristics such as the proximity of supply chain partners, a common shared information system, visibility of inventory levels, and commitment of suppliers and customers, constitute important enablers or starting points to supply chain value creation. We thus propose:

\section{$H_{1}$ : The use of structural mechanisms positively affects supply chain value creation}

\subsubsection{Relationship Building and Value Chain Integration}

A synthesis of interdisciplinary works comprising the fields of sociology, marketing and organizational theory point to relationship building as another important source of initiators (e.g., Cyert and March 1963; Heide 1994; Granovetter 1985). These works point to the importance of binding ties within a social network as a significant influence on strategic decision-making. A logical consequence of this is that efforts by firms to maintain trust and commitment among supply chain partners can make or break the effectiveness of value creation efforts. Empirical studies support these contentions. For example, in an empirical study of buyer-seller relationships within the industrial machinery and equipment distribution industry, Johnson (1999) found that the lengths of relationships with suppliers positively influenced strategic 
integration within distributor firms. In a study of wholesaler-supplier relationships, Brown et al. (1999) found that firms that focused on behavioral issues such as perceptions of fairness and use of informal contracts, enjoyed tighter linkages and flexibility within their supply chains. Parsons (2002) conducted an empirical study of the effects of buyer-seller relationships on buyer performance in 368 firms from a cross section of industries. Results suggested that the quality of the buyer-seller relationship, measured in terms of trust and satisfaction, were significantly related to buyer perceptions of access to their own distribution channels and gains in market share for the buyer firm. Besides the tangible benefits of better integration with downstream partners and increased market share, the quality of the relationship also enhanced the buyer's approval and status within the industry. Based on this evidence, we propose:

$\mathrm{H}_{2}$ : The use of relationship building practices positively affects supply chain value creation.

\subsubsection{Supply Chain Value Creation and Firm Performance}

Several studies have observed a positive relationship between coordinated efforts to generate value within the supply chain and firm performance. Frohlich and Westbrook (2001) reported that supplier integration and customer integration positively influence performance. Morash and Clinton (1998) observed a positive and significant relationship between internal management and performance. They also reported positive and significant relationships between both supplier and customer integration on performance. Teresko (1992) reported on a study that correlated a company's stock price with references in the business press to the company's supply-chain failures. The study found that for these companies, stock prices fell an average of $8.62 \%$ following announcements of failures, and continued to fall by as much as $20 \%$. The business press, and in particular case studies involving recipients of Industry Week's Best Plant 
Award, has repeatedly cited the performance benefits associated with supply chain integration (Drickhamer 2001).

Few studies have undertaken a concurrent examination of the impact of supplier, customer and internal sources of value creation on performance. As indicated earlier, there is also a lack of theory to use in making judgments about the specific ordering of internal and external sources of value creation. Using the limited work that has addressed this issue tangentially (e.g., El Sawy 2001; Fawcett \& Magnan 2001; Frohlich \& Westbrook 2001), we have proposed an overarching construct called supply chain value creation. Similarly, based on the findings of Fawcett and Magnan (2001), Frohlich and Westbrook (2001), and Morash and Clinton (1998), we argue that firm performance is directly affected by the firm's internal and external value creation efforts. The above discussion suggests the following hypothesis:

\section{$H_{3}$ : Supply chain value creation positively affects firm performance.}

\section{Research Method}

\subsection{Survey Methodology}

A survey instrument was developed to collect data to evaluate the hypotheses. Three sources of information were used to identify survey items: a review of the pertinent literature, company documentation, and discussions with practitioners. Based on these sources, nine items (four structural and five behavioral) related to initiators and twenty items (eight customer, six supplier, and six internal process) related to value creation processes, were identified. For each item, a five point Likert scale was developed that focused on the importance of the specific practice in a firm's supply chain management efforts. To assess business performance, four commonly used measures of performance that reflect financial and market performance were identified (Tan et. al 1998; 1999). For each item, a five point Likert scale was developed that 
sought information on the performance of a firm relative to that of major competitors (Appendix 1).

The survey instrument was pre-tested by thirty senior purchasing and materials managers, and where necessary, questions re-worded to improve clarity. Pre-test questionnaires were not used in subsequent analyses. The revised instrument was mailed to senior purchasing and materials managers in North America and Europe identified from the Institute for Supply Management (ISM) and the American Production and Inventory Control Society (APICS) membership lists. Efforts were made to target senior level managers who are more likely to be familiar with their organizations' supply chain management efforts. Following standard mail survey procedures, the original mailing consisted of the survey and a postage-paid self-addressed return envelope. A follow-up reminder in the form of a postcard was mailed two weeks after the original survey was mailed. A second reminder was mailed two weeks later in the form of a duplicate survey and a postage-paid self-addressed envelope. Of the forty five hundred surveys mailed, five hundred and twenty seven usable surveys were returned. The response rate (12\%) was comparable to that obtained in other studies that examined supply chain issues and used similar membership mailing lists (e.g., Fawcett \& Magnan 2001, Frohlich \& Westbrook 2001, Morash \& Clinton 1998). Responding firms varied in size from ten to two hundred thousand employees $($ median $=250)$, and had annual sales of between $\$ 20,000$ and $\$ 30$ billion $($ median $=$ $\$ 30$ million). To test for non-response bias, surveys were separated into two groups based on return date, late arriving surveys considered representative of non-respondents (Armstrong \& Overton 1977; Lambert \& Harrington 1990). T-tests were carried out on responses to a number of randomly selected survey items, the number of employees, and annual sales. No statistically 
significant differences in mean responses were observed indicating the absence of non-response bias.

\subsection{Structural Equation Model Development}

Several authors have suggested the use of a two-step approach to structural equation modeling (e.g., Anderson \& Gerbing 1988; Jöreskog \& Sörbom 1993). Measurement models are first developed to test the construct validity of latent variables. Construct validity reflects the degree to which measures of the same trait correlate higher with each other than with measures of other traits (Schoenfeldt 1984). It is assessed in terms of convergent validity, the degree to which pre-specified measures correlate with the underlying construct(s) predicted by theory, and discriminant validity, the degree of exclusiveness that can be attained by reflective measures, and the absence of incorrect relationships between measured variables and non-hypothesized constructs. Once the construct validities of latent variables has been established by the measurement models, the structural model defining hypothesized direct and indirect relations among latent variables can be tested. This allows predictive validity to be evaluated.

A structural equation model is only reliable if its parameter values can be estimated (Raykov \& Marcoulides 2000). This requires that the model be identified. A necessary condition for identification is that the model must have a positive number of degrees of freedom. If the measurement and structural models are separated and the measurement models identified independently, the structural model will be identified (Maruyama 1998). Sample size also affects the ability to correctly estimate parameter values and determine model fit (Schumacker \& Lomax 1996). Adequacy of sample size can be determined either in terms of the total sample size or in terms of the number of cases per variable. Using the former approach, Anderson and Gerbing (1988) suggested a minimum sample size of one hundred and fifty. Using the latter approach, 
five cases per variable are sufficient for normal and elliptical distributions, and ten cases per variable for other distributions (Bentler \& Chou 1987). Since the model contains forty-two indicators and six latent variables, a sample size of five hundred and twenty seven is ample.

Measurement and structural models were developed using LISREL-SIMPLIS 8.30 (Byrne 1998; Jöreskog \& Sörbom 1993). Maximum likelihood (ML) estimation, which assumes multivariate normality of the observed variables, was used. Although this method requires observations be independently and identically distributed (Schumacker \& Lomax 1996), it is robust to minor deviations from normality (Raykov \& Marcoulides 2000). Since each latent variable is estimated from the corresponding set of measured variables, it has no absolute metric scale. A common modeling approach is to map the corresponding latent variable onto its measured variables by constraining one measured variable to have a value of 1.0 (Byrne 1998). Thus, the first parameter estimate in each measurement model in this study was fixed at 1.0.

\subsection{Analysis of Measurement Models}

Analysis of the structural mechanisms measurement model indicated that all parameter estimates exhibited the correct sign and size and were consistent with underlying theory (Byrne 1998). Parameter estimates shown are standardized solutions (Figure 2). Although several goodness-of-fit criteria/tests have been proposed ${ }^{1}$, no single test or index can absolutely identify a correct model (Schumacker \& Lomax 1996). The comparative fit index (CFI) and normed fit index (NFI) are however the preferred measures (Bentler 1992), though the non-normed fit index (NNFI, Bentler 1990) and the ratio of $\chi^{2}$ to degrees of freedom $\left(\chi^{2} / \mathrm{df}\right)$ are also routinely used. Non-significant $\chi^{2}$ p-values imply the data fit the hypothesized model. The value of $\chi^{2}$ is however sensitive to sample size and departures from multivariate normality. Large sample size

\footnotetext{
${ }^{1}$ A list of model fit indices and corresponding acceptance criteria can be found in Raykov and Marcoulides (2000).
} 
(for example, larger than 200) tends to result in significant $\chi^{2}$ statistics. Most recent structural equation modeling research has thus used the ratio $\chi^{2} / \mathrm{df}$ as a measure of model fit. Values for several measures of model fit are presented in Table 2 along with corresponding values indicative of good model fit. Fit indices are consistent with good model fit.

\section{Insert Figure 2 about here}

\section{Insert Table 2 about here}

Modification indices suggested adding several error covariance terms to the relationship building measurement model ${ }^{2}$. Two centered on the item searching for new ways to integrate within the supply chain (Q2B), and implied a positive correlation between the item and items relating to improving integration activities (Q2A), and establishing more frequent contacts with supply chain partners (Q2C). A third indicated positive correlation between involving supply chain members in the firms' activities (Q2D) and extending the supply chain beyond immediate members (Q2E). Searching for new ways to integrate supply chain partners into a firms activities can only be accomplished by improving contact with partners and is only going to be successful if existing efforts are meaningful and effective. Similarly the logical next step to involving supply chain members in a firm's activities is to go beyond first tier suppliers and customers and to involve suppliers and customers further upstream and downstream respectively. Covariance terms were added and the measurement model modified accordingly (Figure 3). Fit indices suggest that the revised model fit the data well (Table 2). 


\section{Insert Figure 3 about here}

Modification indices suggested adding three error covariance terms to the customer value measurement model. These suggested positive correlations between determination of customer expectations (Q3B) and making it easier for customers to seek assistance (Q3C), between employing a customer satisfaction measurement system (Q3D) and determining factors for improving customer satisfaction $(\mathrm{Q} 3 \mathrm{E})$, and between employing routine follow up procedures (Q3G) and interacting with customers to set goals $(\mathrm{Q} 3 \mathrm{H})$. Creating value via customers implies not only understanding customer needs but facilitating efforts to respond to them. Moreover, it implies commitment to developing ways to assess whether needs are being responded to and met accordingly. The model was revised (Figure 4) and exhibited good fit with the data (Table 2).

\section{Insert Figure 4 about here}

Modification indices suggested that two error covariance terms be added to the supplier value measurement model. These suggested positive correlation between emphasis on quality in supplier selection (Q4E) and both the sharing of confidential information (Q4C) and commitment to continuous improvement (Q4F). Examining a supplier's willingness to share information and commitment to continuous improvement are both indicative of a commitment to quality in supplier selection. The revised model (Figure 5) fit the data well (Table 2).

\footnotetext{
${ }^{2}$ While some researchers question the addition of error covariance terms, it is considered to be common and acceptable practice if there is a theoretical basis to support the corresponding correlations (Byrne, 1998). Moreover,
} 


\section{Insert Figure 5 about here}

Two covariance terms were added to the internal process value measurement model. These reflected positive correlations between reducing setup time (Q5B) and reducing lot size (Q5A), and between reducing the supplier base (Q5C) and buying from JIT suppliers (Q5D). The relationship between setup time reduction and lot size reduction is well documented in the JIT literature, as has the relationship between contraction of the supply base and the use of JIT suppliers. Covariance terms were thus added to the measurement model (Figure 6), which fit the data well (Table 2).

\section{Insert Figure 6 about here}

A single covariance term signifying a negative correlation between market share performance (Q6A) and overall customer service levels (Q6D) was indicated for the performance measurement model (Figure 7). This is consistent with increased market share causing deterioration in customer service levels due to demand outpacing production and the inability of the existing infrastructure to support customer service needs. The rapid growth of the direct sales personal computer industry in the 1990s which led to consumers encountering long hold times when seeking technical support, illustrates this phenomenon. The measurement model, duly modified (Figure 7), fit the data well (Table 2).

\section{Insert Figure 7 about here}

their addition will not improve the fit of a poorly fit model. 


\subsection{Analysis of Structural Model}

To provide further evidence of convergent and discriminant validity of the constructs, confirmatory factor analysis (CFA) was conducted to analyze the six measurement models simultaneously (Schumacker \& Lomax 1996). Results are shown in Table 2 and provide further support for the validity of the measurement models. Having established the validity of the measurement models, the proposed structural model was tested. Goodness of fit indices suggested good model fit (Table 2). For example, the values of CFI and NNFI were 0.94 and 0.93 respectively, and the ratio of $\chi^{2}$ to degrees of freedom was 2.31 .

Hypothesis 1 proposed a positive relationship between the use of structural mechanisms and supply chain value creation. The significant standardized path coefficient of 0.19 (Figure $8, \mathrm{t}$ $=3.47, \mathrm{p}<0.01)$ indicates that there is support for this hypothesis. Hypothesis 2 stated that there was a positive relationship between the use of relationship building mechanisms and supply chain value creation. The standardized path coefficient of $0.57(t=7.09, \mathrm{p}<0.01)$ was again significant indicating support for the hypothesis. Hypothesis 3 stated that supply chain value creation has a positive relationship with firm performance. As can be seen from Figure 8, this hypothesis was strongly supported (standardized estimates of $0.41, \mathrm{t}=5.94$, and significant at $\mathrm{p}<0.01$ )

\section{Insert Figure 8 about here}

\section{Discussion}

Literature from fields including organization theory and operations management, have hinted at the importance of structural initiators as a driver of organizational performance. Similarly, the marketing, strategy and sociology literature have alluded to the importance of relationship building as a starting point for attempts at value creation. To our knowledge 
however, the present study is the first to simultaneously address the influence of structural and behavioral mechanisms as initiators of successful supply chain value creation efforts, and more importantly, to empirically examine their impact. Results support the underlying contention that both structural and relationship building mechanisms significantly and positively impact value creation efforts. This is an important result in that it provides evidence of the need to examine the groundwork that needs to be laid prior to efforts to leverage the supply chain to create value and not just the processes used to create value itself. The development of value creation processes should not occur in a vacuum, but in the context of broader strategic and operational objectives. While the development of actions based on an underlying strategy is a common theme in the literature, it is not uncommon in practice for processes to be developed in a piecemeal manner, driven by short-term goals, for example cost reduction, without consideration of broader strategic objectives. The results suggest that this disconnect between the why and how of value creation may help to explain the limited success of supply chain management efforts.

The results also provide initial support for the validity of the structural and relationship building mechanisms constructs proposed. While the primary objective of the current study was not to develop comprehensive, rigorous scales for the two constructs, the validity of the five items comprising the structural mechanisms construct and the nine items representing the relationship building construct, provide the basis for follow-up studies whose research objective is to identify valid scales in the nomological network of constructs in supply chain management.

Another objective of this paper was to identify the sources of value within the supply chain and to propose a method of operationalization of internal and external value creation mechanisms. As stated earlier, arbitrarily selecting and implementing a set of internal and external value creation mechanisms believed to positively affect performance is troublesome and 
can lead to failures of value creation efforts. This study illustrates that a broad set of twenty practices can be empirically classified into three factors; customer value, supplier value, and internal process value. These factors in turn reflect the overarching construct of supply chain value creation. Rigorous testing using structural equation modeling provides support for the inclusion of the constituent practices within the three factors. While the eight customer, six supplier, and six internal process value practices do not represent an exhaustive set of effective practices, they were identified as valid components of internal and external efforts that span the supply chain value construct.

Supply chain value creation displayed a positive effect on firm performance. This result is consistent with others in the operations management literature, which has repeatedly spoken of the importance of leveraging supply chain partnerships as a driver of organizational success. Frohlich and Westbrook (2001) for example found that firms that focus simultaneously on supplier and customer integration (i.e., a broad 'arc' of integration) enjoy improvements on a wide range of firm performance measures. More recently, Rosenzweig et al. (2003) observed a positive relationship between integration intensity and business performance. While the focus of the current study was not on integration per se but on sources of value within the supply chain, a similar conclusion can be drawn, namely that understanding where sources of value lie within the supply chain reside and leveraging these sources, has a direct bearing on performance.

\section{Conclusions}

This research offers several distinctive contributions. The results suggest that the extent of value creation in supply chains is dependent on the attention placed on key initiating mechanisms: structural mechanisms and relationship building. Put simply, this means that firms with superior capabilities in channeling the structural mechanisms identified in the study as well 
as in building relationships with key boundary spanning entities are able to develop and sustain higher levels of value. High levels of value creation are in turn positively associated with superior firm performance. This has implications for supply chain design and configuration. As Frohlich and Westbrook (2001) noted, few studies have examined the necessary steps needed or 'routes taken' to achieve integration within the supply chain. Moreover, they pointed out that few studies have identified the 'forces of inertia' that inhibit firms from successfully leveraging their supply chains. This study fills both these voids. It also meets the frequent call among OM researchers to make attempts at theory building (e.g., Handfield \& Melynk 1998, Meredith 1998). Not only has a theory of how to leverage supply chain value creation efforts been proposed and tested, key constructs have been operationalized and validated, providing a starting point for future studies. Given the increasing interest in getting the most out of supply chains, this is of some significance. As noted by Schmenner and Swink (1998) and by Frohlich and Westbrook (2001), there is a vital need for researchers in operations management to carry out richer, more detailed examinations of initial patterns discerned from prior empirical research studies.

The study is not without its limitations. Internal process value was operationalized using a single construct. A decision was made to focus on a cross-functional process view of internal process value rather than adopting a more functional focus. For example, information flow could be viewed as a distinct source of value worthy of being separated from internal process value as operationalized. Environmental factors can have a differential influence on initiators as well as value creation mechanisms. For example, the complexity, hostility, and dynamism of the environment, industry concentration, and market dominance, can influence initiators and value creation mechanisms. In the interest of brevity, we did not consider the environmental impact 
associated with these variables. We also relied on a single respondent from within the sourcing and materials management function of firms to collect our data. While these managers were assumed to be knowledgeable about key issues affecting their firm's supply chains, it is conceivable that their responses on performance measures beyond their immediate purview are approximations which could be a source of bias. The results must thus be interpreted with caution to avoid unwarranted generalizations. Future studies could use a triangulation of evidence from multiple sources and/or segments to verify the robustness of our results. For example, combined views of key respondents from sourcing, operations, logistics and customer support might offer an enriched insight into the role of initiators and value creation on performance. Another direction for future research is to examine the effects of contingency variables such as firm size, type of product, and the firm's position in the expanded supply chain (including the supplier's suppliers and customers of the immediate customer) on the relationships between initiators, value creation and firm performance. 


\section{REFERENCES}

ALDERSON, W. 1965. Marketing Behavior and Executive Action: A Functionalist Approach to Marketing Theory, (Homewood, IL: Irwin-McGraw Hill).

ANDERSON, J.C., \& GERBING, D.W. 1988. Structural equation modeling in practice: A review and recommended two-step approach. Psychological Bulletin, 103 (3), 411-423.

ARMISTEAD, C.G., \& MAPES, J. 1993, The Impact of Supply Chain Integration on Operating Performance. Logistics Information Management, 6 (4), 9-14.

ARMSTRONG, J.S., \& OVERTON. T.S., 1977, Estimating non-response bias in mail surveys. Journal of Marketing Research, 14 (3), 396-402.

BARNEY, J., 1991, Firm resources and sustained competitive advantage. Journal of Management. 17, 99-120.

BARTHOLOMEW, D., 1999, The infrastructure, Industry Week, 248 (16), 62-66.

BENTLER, P.M., 1990, Comparative fit indexes in structural models. Psychological Bulletin, 107, 238-246.

BENTLER, P.M., 1992, On the fit of models to covariances and methodology. Psychological Bulletin, 112 (3), 400-404.

BENTLER, P.M., \& CHOU, C., 1987, Practical issues in structural modeling. Sociological Methods and Research, 16, 78-117.

BLACK, J.A., \& BOAL, K.B., 1994, Strategic resources: Traits, configurations and paths to sustainable competitive advantage. Strategic Management Journal, 15 (2), 131-148.

BROWN, J., COBB, A. T., \& LUSCH, R., 1999, The behavioral side of supply chain relationships: The roles that contracts and justice play in satisfaction and conflict. Proceedings of the Academy of Management, Chicago, IL.

BYRNE, B. M., 1998, Structural equation modeling with Lisrel, Prelis, and Simplis: Basic concepts, applications, and programming. Lawrence Erlbaum Associates: Mahwah.

CHANDLER, A.D., 1962, Strategy and Structure. MIT Press: Cambridge.

CHENG, J.L.C., 1983, Interdependence and coordination in organizations: A role-system analysis. Academy of Management Journal, 26, 156-162.

CHOI, T.Y., \& EBOCH, K., 1998, The TQM paradox: Relations among TQM practices, plant performance, and customer satisfaction," Journal of Operations Management, 17, 59-75.

COASE, R., 1937, The nature of the firm. Economics N.S., 4. Reprinted in G. J. Stigler \& K. E. Boulding (Eds.), Readings in Price Theory, 1952. Irwin: Homewood IL. 
CYERT, R.M., \& MARCH, J.G., 1963, A behavioral theory of the firm. Prentice Hall: Englewood Cliffs.

D'AVENI, A., 1978, Organizational linkages and resource mobilization: The significance of linkage strength and breadth. The Sociological Quarterly, 19, 185-202.

DRICKHAMER, D., 2001, Trailblazers. Industry Week, 250 (9), 13-15.

DYER, J.H., \& SINGH, H., 1998, The relational view: Cooperative strategy and sources of interorganizational competitive advantage. Academy of Management Review, 23, 660-679.

DYER, J.H., CHO, D.S. \& CHU, W., 1998, Strategic Supplier Segmentation: The Next "Best Practice" in Supply Chain Management. California Management Review, 40, 2, 57-77.

EL SAWY, O., 2001, Redesigning Enterprise Processes for E-Business. Irwin-McGraw Hill: Columbus.

FAWCETT, S.E., \& MAGNAN, G.M., 2001, Achieving World-Class Supply Chain Alignment: Barriers, Bridges, and Benefits, Center for Advanced Purchasing Studies (CAPS) Focus Study, Center for Advanced Purchasing Press, Tempe, AZ.

FISHER, M., 1997, What is the right supply chain for your product? A simple framework can help you figure out the answer. Harvard Business Review, 36, 105-116.

FROHLICH, M. T., \& WESTBROOK, T., 2001, Arcs of Integration: An International Study of Supply Chain Strategies. Journal of Operations Management, 19 (2), 185-200.

GILBERT, S. M., \& BALLOU, R. H., 1999, Supply chain benefits from advanced customer commitments. Journal of Operations Management, 18 (1), 61-73.

GOVERS, C.P.M., 2001, QFD not just a tool but a way of quality management. International Journal of Production Economics, 69 (2), 151-159.

GRANOVETTER, M., 1985, Economic action and social structure: The problem of embeddedness. American Journal of Sociology, 91 (3), 481-510.

HAMMER, M., \& CHAMPY, J., 1993, Reengineering the Corporation. Harper Business: New York.

HANDFIELD, R.B., \& BECHTEL, C., 2002, The role of trust and relationship structure in improving supply chain responsiveness. Industrial Marketing Management, 31, 367-382.

HANDFIELD, R.B., \& MELNYK, S.A., 1998, The scientific theory-building process: A primer using the case of TQM. Journal of Operations Management, 16 (4), 321-339.

HANDFIELD, R.B., KRAUSE, D.R., SCANNELL, T.V., \& MONCZKA, R.M., 2000, Avoid the Pitfalls in Supplier Development. Sloan Management Review, 41 (2), 37-49. 
HAUSER, J.R., \& CLAUSING, D., 1988, The House of Quality. Harvard Business Review, 66 (3), 63-73.

HAUSMAN, W.H., MONTGOMERY, D.B., \& ROTH, A.V., 2002, Why should marketing and manufacturing work together? Some exploratory empirical results. Journal of Operations Management, 20 (3), 241-257.

HEIDE, J. B., 1994, Inter-Organizational Governance in Marketing Channel. Journal of Marketing, 58, 781-85.

HEIDE, J., \& JOHN, G., 1988, The role of dependence balancing in safeguarding transactionspecific assets in conventional channels. Journal of Marketing, 52, 20-35.

HILL, T., 1994, Manufacturing strategy: Text and cases. Irwin: Homewood.

JANSSEN, M., \& SOL, H., 2000, Evaluating the role of intermediaries in the electronic value chain. Internet Research: Electronic Networking Applications and Policy, 10, 5-14.

JOHNSON, J. L., 1999, Strategic Integration in Industrial Distribution Channels: Managing the Interfirm Relationship as a Strategic Asset. Academy of Marketing Science, 5 (4), 4-18.

JÖRESKOG, K.G., \& SÖRBOM, D. 1993, LISREL8: Structural equation modeling with the SIMPLIS command language. Hillsdale: Lawrence Erlbaum Associates.

KOLOSZYC, G., 1998, Retailers, suppliers push joint sales forecasting. Stores, 80 (6), 28-31.

KUMAR, N., 1996, The power of trust in manufacturer-retailer relationships. Harvard Business Review, 92-107.

LAMBERT, D. M., \& HARRINGTON, T.C., 1990, Measuring non-response bias in mail surveys. Journal of Business Logistics, 11 (2), 5-25.

LAMMING, R., 1993, Beyond Partnership: Strategies for Innovation and Lean Supply, Prentice Hall: London.

LAWRENCE, C., 2000, Ten pitfalls to avoid in choosing CRM systems. Call Center Solutions, 19 (2), 56-59.

MARTINS, A., \& ASPINWALL, E.M., 2001, Quality function deployment: An empirical study in the UK. Total Quality Management, 12 (5), 575-588.

MARUYAMA, G.M., 1998, Basics of structural equation modeling. Sage Publications: Thousand Oaks.

MCWILLIAMS, A. \& GRAY, S., 1995, Understanding quasi-integration. Journal of Business Strategies, 12, 69-85.

MEREDITH, J., 1998, Building operations management theory through case and field research. Journal of Operations Management, 16 (4), 441-454. 
MOENAERT, R., SOUDER, W., DE MEYER, A., \& DESCHOOLMEESTER, D., 1994, R\&Dmarketing integration mechanism, communication flows, and innovation success. Journal of Product Innovation Management, 11, 31-45.

MORASH, E. A., \& CLINTON, S. R., 1998, Supply chain integration: Customer value through collaborative closeness versus operational excellence. Journal of Marketing Theory and Practice, 6 (4), 104-120.

MORGAN, R.M., \& HUNT, S.D., 1994, The commitment-trust theory of relationship marketing. Journal of Marketing, 58, 20-38.

NARASIMHAN, R., JAYARAM, J., AND CARTER, J., 2001, An Empirical Examination of the Underlying Dimensions of Purchasing Competence, Production and Operations Management Journal, 10(1), 1-15.

NARVER, J.C., \& SLATER, S.F., 1990, The effect of a market orientation on business profitability, Journal of Marketing, 54, 20-35.

PARSONS, A.L., 2002, What determines buyer-seller relationship quality? An investigation from the buyer's perspective. Journal of Supply Chain Management, 28 (2), 4-12.

PETERSON, K., 2002, Collaboration lessens supply chain swings. Semiconductor International, $25(1), 65-66$.

PFOHL, H., \& MAYER, S., 1999, Insights to Impact, Results of the Fourth Quinquennial European Logistics Study, ELA European Logistics Association / A.T. Kearney, Brussels.

POPPO, L., \& ZENGER, T., 1998. Testing alternative theories of the firm: Transaction cost, knowledge-based, and measurement explanations for make-or-buy decisions in information services. Strategic Management Journal, 19, 853-877.

POWERS, T. L., STERLING, J. U., \& WOLTER, J. F., 1988, Marketing and manufacturing conflict: Sources and resolution. Production and Inventory Management Journal, 56-60

PRESCOTT, E.C., 1999, The multinational corporation as a coordinated network: Organizing and managing differently. Thunderbird International Business Review, 41 (3), 291-322.

RAMDAS, K., \& SPEKMAN, R.E., 2000, Chain or Shackles: Understanding what drives supply-chain performance, Interfaces, 30 (4), 3-21.

RASHEED, H.S., \& GEIGER, S.W., 2001, Determinants of governance structure for the electronic value chain: Resource dependency and transaction costs perspectives. Journal of Business Strategies, 18 (2), 159-176.

RAYKOV, T., \& MARCOULIDES, G.A., 2000, A First Course In Structural Equation Modeling. Lawrence Erlbaum Associates: Mahwah. 
REUKERT, R. W., \& WALKER, O. C., JR., 1987, Marketing's interaction with other functional units: A conceptual framework and empirical evidence. Journal of Marketing, 51, 1-19.

RHO, B. H., HAHM, Y. S., \& YU, Y. M., 1994, Improving interface congruence between manufacturing and marketing in industrial-product manufacturers. International Journal of Production Economics, 37 (1), 27-40.

RINDFLEISCH, A., 1997, Transaction cost analysis: Past, present, and future applications. Journal of Marketing. 61, 30-55.

ROSENZWEIG, E., ROTH, A., AND DEAN, R., 2003., The influence of an integration strategy on competitive capabilities and business performance: An exploratory study of consumer products manufacturers, Journal of Operations Management, 21, 437-456.

SCHOENFELDT, L.F., 1984, Psychometric properties of organizational research instruments. In Methods and Analysis in Organizational Research, T. Bateman and G. Ferris (eds.), Reston Publishing Company: New York.

SCHONBERGER, R.J., 1982, Japanese Manufacturing Techniques, The Free Press: New York.

SCHUMACKER, R.E., \& LOMAX, R.G., 1996, A beginner's guide to structural equation modeling. Lawrence Erlbaum Associates: Mahwah.

SCHMENNER, R.W., AND SWINK., M.L., 1998, On theory in operations management, Journal of Operations Management, 17, 97-113.

SIMESTER, D., \& KNEZ, M., 2002, Direct and Indirect Bargaining Costs and the Scope of the Firm, Journal of Business, 75(2), 283-304.

SONG, M.X., NEELEY, S.M., \& ZHAO, Y., 1996, Managing R\&D-marketing integration in the new product development process. Industrial Marketing Management, 25, 545-553.

TAN, K.C., KANNAN, V.R., HANDFIELD, R.B., \& GHOSH, S., 1999, Supply Chain Management: An Empirical Study of Its Impact on Performance, International Journal of Operations \& Production Management, 19(10), 1034-1052.

TAN, K.C., HANDFIELD, R.B., \& KRAUSE, D.R. 1998, Enhancing The Firm's Performance through Quality and Supply Base Management: An Empirical Study, International Journal of Production Research, 36(10), 2813-2837.

TERESKO, J., 2002, Supply-chain losers. Industry Week, 251 (1), 19-20.

TSANG, E., 2000, Transaction cost and resource-based explanations of joint ventures: A comparison and synthesis. Organization Studies, 21, 215-242.

TURNBULL, P., OLIVER, N., \& WILKINSON, B., 1992, Buyer-Supplier Relations in the UK automotive industry: Strategic implications of the Japanese manufacturing model. Strategic Management Journal, 13, 159-168. 
WAGNER, M., 2000, Dell's hard lesson - Integration with customer systems proves onerous. Internetweek, 829, 1 \& 74.

WERNERFELT, B. 1984,. A resource-based view of the Firm, Strategic Management Journal, 5, 171-180.

WERNERFELT, B., 1997. On the Nature and Scope of the Firm: An Adjustment-Cost Theory. Journal of Business, 70 (4), 489-514.

WILLIAMSON, O. 1981. The Economics of Organization: The Transaction Cost Approach. American Journal of Sociology, 87, 548-77.

WILLIAMSON, O. E. 1975,. Markets and hierarchies: Analysis and antitrust implications. Free Press: New York.

WILLIAMSON, O.E., 1999. Strategy research: Governance and competence perspectives. Strategic Management Journal, 20, 1087-1108.

WOMACK, J.P., JONES, D.T., \& ROOS, D. 1990,. The Machine that Changed the World. Rawson Associates: New York.

ZHAO, X, XIE, J., \& WEI, J.C. 2002, The impact of forecast errors on early order commitment in a supply chain. Decision Sciences, 33 (2), 251-280. 
Table 1: Theoretical Support for the Research Model

\begin{tabular}{|c|c|c|}
\hline Theory or (Grounded Theory) & Supporting Theme & Key References \\
\hline Transaction Cost Economics & $\begin{array}{l}\text { Firms consider attributes of transactions } \\
\text { when deciding whether to use internal } \\
\text { governance mechanisms or external } \\
\text { market mechanisms. }\end{array}$ & $\begin{array}{l}\text { Coase (1937); Williamson } \\
\text { (1975); Hiede \& John } \\
\text { (1988); Rindfleish (1997) }\end{array}$ \\
\hline $\begin{array}{l}\text { Resource Based View of the } \\
\text { Firm }\end{array}$ & $\begin{array}{l}\text { Whether to use internal governance } \\
\text { mechanisms or external market } \\
\text { mechanisms should be based on the } \\
\text { acquisition and exploitation of inimitable } \\
\text { resources. }\end{array}$ & $\begin{array}{l}\text { Barney (1991); Wernerfelt } \\
\text { (1984); Poppo \& Zenger } \\
\text { (1998); Rasheed \& Geiger } \\
\text { (2001) }\end{array}$ \\
\hline Organizational Theory & $\begin{array}{l}\text { Structural Mechanisms precede } \\
\text { successful integration efforts. In } \\
\text { particular, design and control of inter- } \\
\text { organizational structures precedes } \\
\text { successful integration. }\end{array}$ & Chandler (1962) \\
\hline $\begin{array}{l}\text { Lean Systems / Reengineering } \\
\text { (Grounded Theory) }\end{array}$ & $\begin{array}{l}\text { Processes are the building blocks of } \\
\text { value in systems. Value generation is } \\
\text { enhanced in systems that eliminate } \\
\text { 'waste' from transactions, activities and } \\
\text { processes. }\end{array}$ & $\begin{array}{l}\text { Womack et al (1990); } \\
\text { Hammer \& Champy (1993); } \\
\text { Schonberger (1982) }\end{array}$ \\
\hline $\begin{array}{l}\text { Boundary Spanning View of } \\
\text { Attachment }\end{array}$ & $\begin{array}{l}\text { Congruence to common bases of } \\
\text { reference and value systems bind or align } \\
\text { inter-organizational relationships. }\end{array}$ & $\begin{array}{l}\text { D'Aveni (1978); } \\
\text { Granovetter (1985) }\end{array}$ \\
\hline Social Network Theory & $\begin{array}{l}\text { Organizations consist of actors. The } \\
\text { behaviors of actors in linked } \\
\text { organizations, defines whether } \\
\text { organizations will have harmonious or } \\
\text { conflicting relationships. }\end{array}$ & $\begin{array}{l}\text { Cyert and March (1963); } \\
\text { Granovetter (1985) }\end{array}$ \\
\hline Organized Behavior System & $\begin{array}{l}\text { An organized behavior system makes } \\
\text { decisions that balance the costs and risks } \\
\text { faced by all channel participants. }\end{array}$ & Alderson (1965) \\
\hline
\end{tabular}




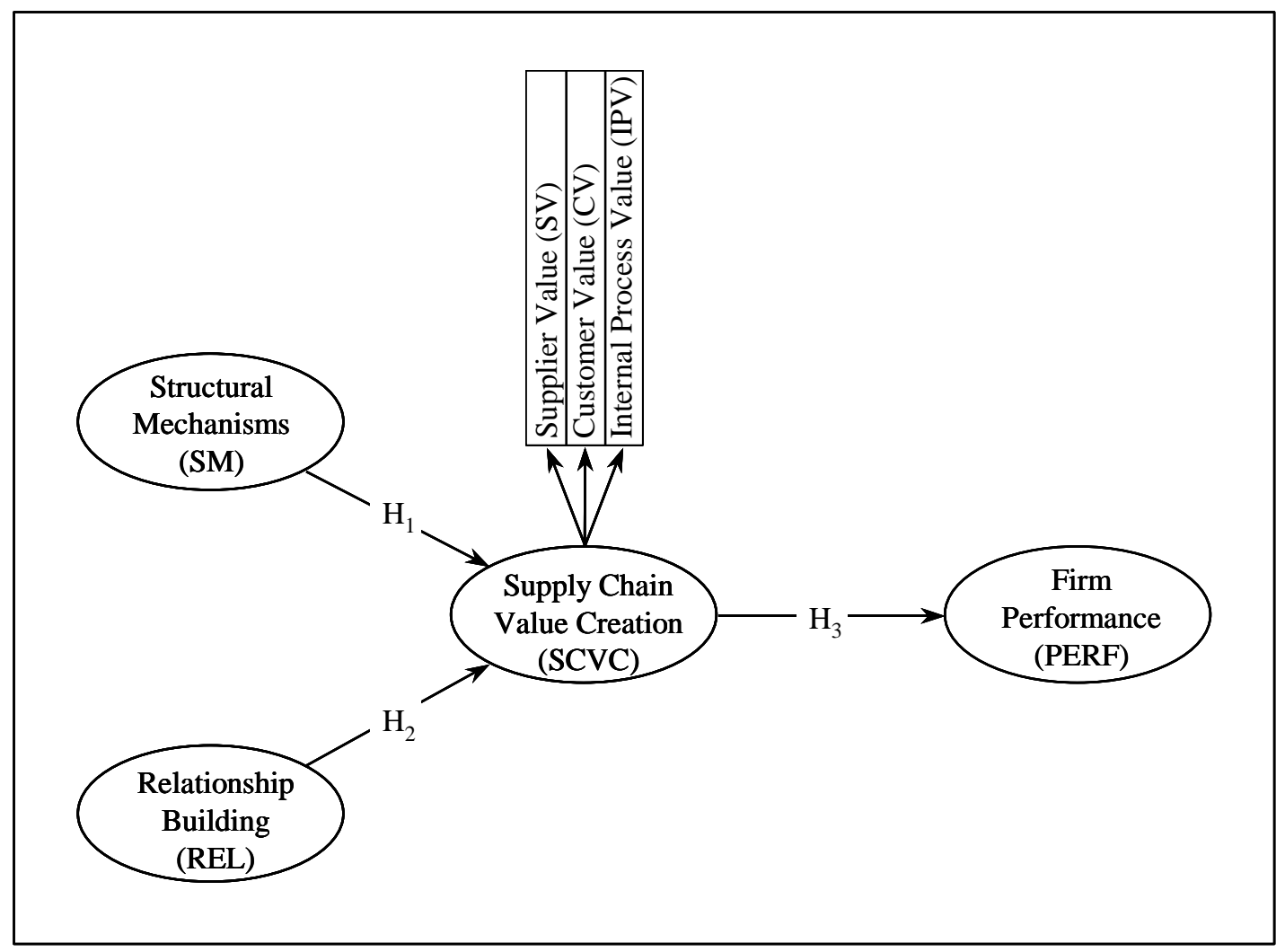

Figure 1: Proposed Research Model

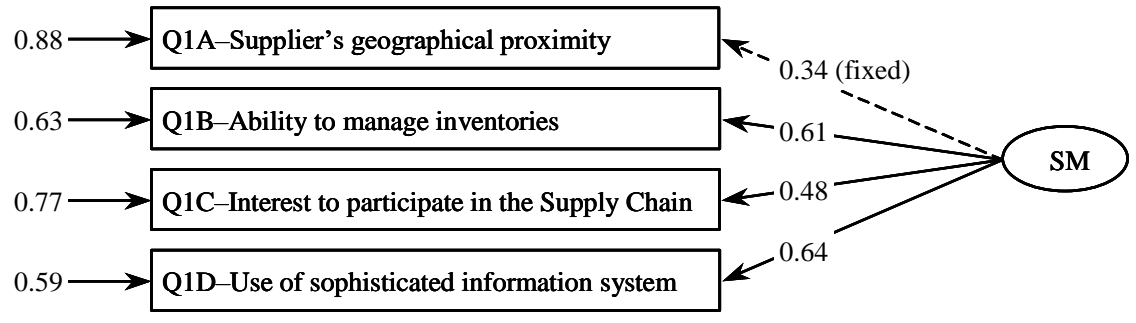

Figure 2: Structural Mechanisms Measurement Model 




Figure 3: Relationship Building Measurement Model

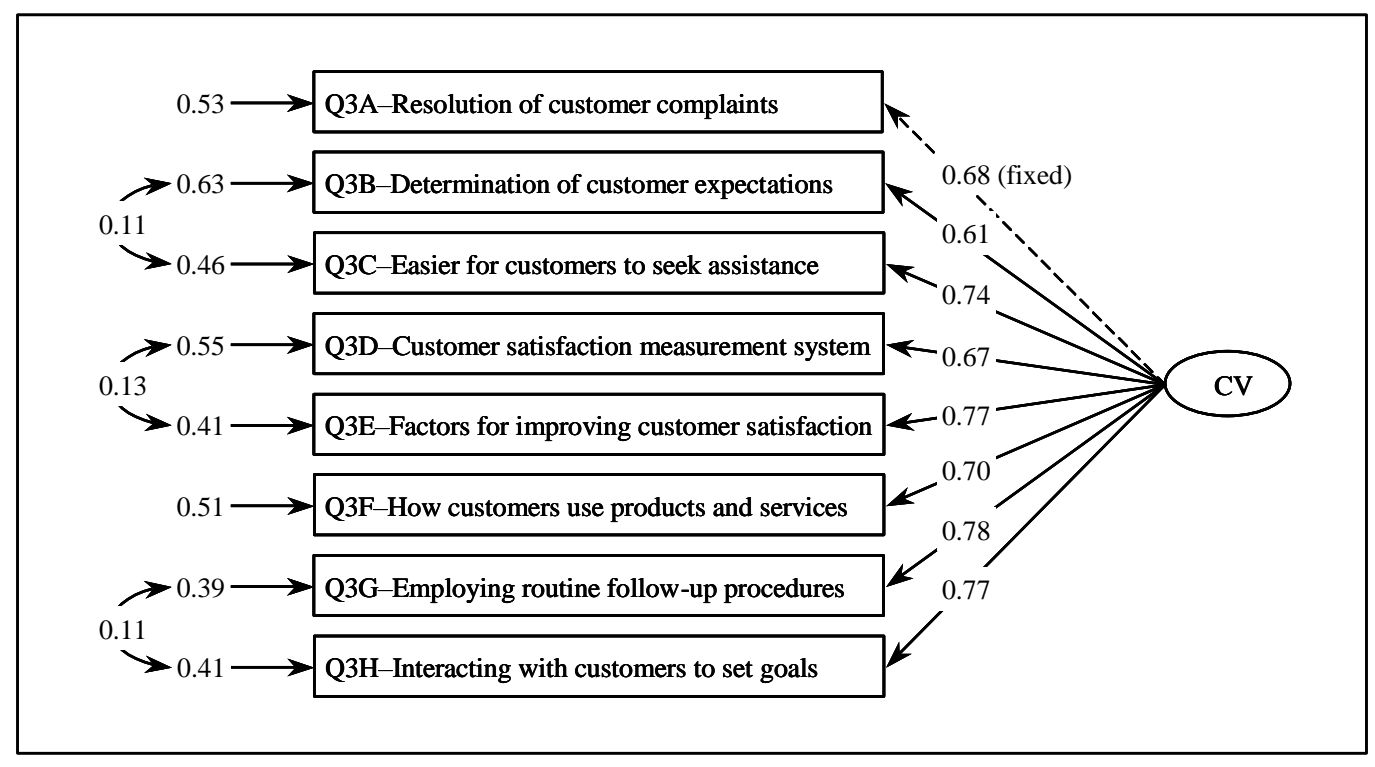

Figure 4: Customer Value Measurement Model 




Figure 5: Supplier Value Measurement Model

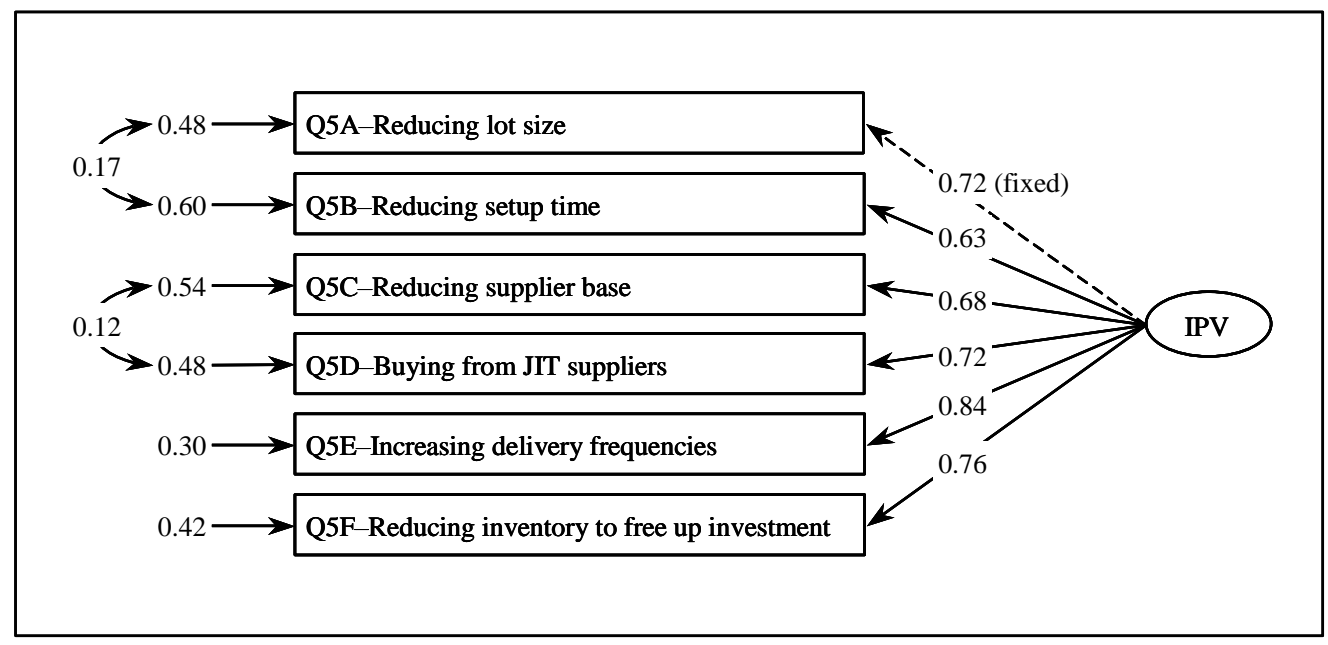

Figure 6: Internal Process Value Measurement Model 




Figure 7: Firm Performance Measurement Model

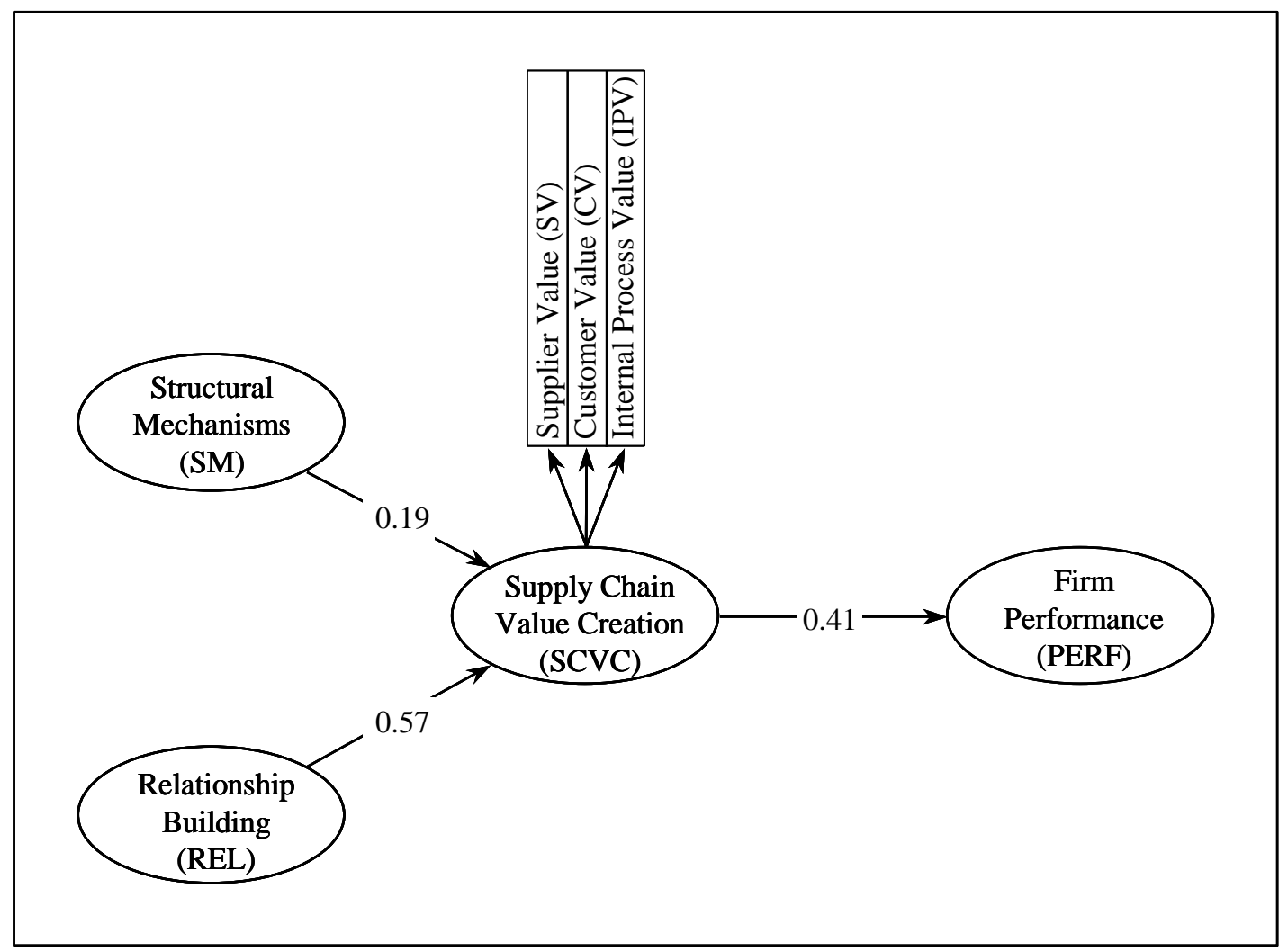

Figure 8: Structural Equation Model 
Table 2: Goodness of Fit Measures

\begin{tabular}{|c|c|c|c|c|c|c|c|c|c|}
\hline \multirow{2}{*}{ GOODNESS-OF-FIT INDEX } & \multirow{2}{*}{$\begin{array}{l}\text { ACCEPTABLE } \\
\text { LEVEL }\end{array}$} & \multicolumn{6}{|c|}{ MEASUREMENT MODELS } & \multirow{2}{*}{ CFA } & \multirow{2}{*}{$\begin{array}{l}\text { STRUCTURAI } \\
\text { MODEL }\end{array}$} \\
\hline & & SM & REL & $\mathrm{CV}$ & SV & IPV & PERF & & \\
\hline$\chi^{2}$ & - & 1.54 & 3.52 & 24.27 & 11.51 & 14.06 & 1.59 & 219.75 & 237.44 \\
\hline degrees of freedom (df) & - & 2 & 2 & 17 & 7 & 7 & 1 & 95 & 97 \\
\hline$\chi^{2} /$ degrees of freedom & $\leq 3.00$ & 0.770 & 1.760 & 1.428 & 1.644 & 2.009 & 1.590 & 2.313 & 2.448 \\
\hline$\chi^{2} \mathrm{p}$-value & $\geq 0.05$ & 0.464 & 0.172 & 0.112 & 0.118 & 0.050 & 0.208 & 0.000 & 0.000 \\
\hline $\begin{array}{l}\text { Root Mean Square Error of } \\
\text { Approximation (RMSEA) }\end{array}$ & $\leq 0.05$ & 0.000 & 0.038 & 0.029 & 0.035 & 0.044 & 0.033 & 0.050 & 0.052 \\
\hline $\begin{array}{l}\text { Standardized Root Mean } \\
\text { Square Residual (Std RMR) }\end{array}$ & $\leq 0.05$ & 0.011 & 0.012 & 0.017 & 0.019 & 0.017 & 0.009 & 0.056 & 0.060 \\
\hline Goodness of Fit Index (GFI) & $\geq 0.90$ & 1.00 & 1.00 & 0.99 & 0.99 & 0.99 & 1.00 & 0.95 & 0.95 \\
\hline Adjusted GFI (AGFI) & $\geq 0.80$ & 0.99 & 0.98 & 0.98 & 0.98 & 0.97 & 0.98 & 0.93 & 0.93 \\
\hline Normed Fit Index (NFI) & $\geq 0.90$ & 0.99 & 1.00 & 0.99 & 0.99 & 0.99 & 1.00 & 0.91 & 0.90 \\
\hline Non-Normed Fit Index (NNFI) & $\geq 0.90$ & 1.00 & 0.99 & 0.99 & 0.99 & 0.99 & 0.99 & 0.93 & 0.92 \\
\hline Comparative Fit Index (CFI) & $\geq 0.90$ & 1.00 & 1.00 & 1.00 & 1.00 & 0.99 & 1.00 & 0.94 & 0.94 \\
\hline Incremental Fit Index (IFI) & $\approx 1$ & 1.00 & 1.00 & 1.00 & 1.00 & 1.00 & 1.00 & 0.94 & 0.94 \\
\hline Relative Fit Index (RFI) & $\approx 1$ & 0.98 & 0.98 & 0.98 & 0.98 & 0.98 & 0.98 & 0.88 & 0.88 \\
\hline Critical N $(\mathrm{CN})$ & $\geq 200$ & 3102 & 1371 & 718 & 833 & 678 & 2196 & 309.47 & 295.30 \\
\hline
\end{tabular}




\section{Appendix 1}

\section{Structural Mechanisms (SM)}
A. Your suppliers' geographical distance from your facilities
B. Ability to manage inventories throughout the entire supply chain
C. Interest among your suppliers and customers in participating in your supply chain
D. Use of sophisticated information system for information sharing among supply chain members

\section{Relationship Building (REL)}
A. Improving the integration of activities across your supply chain
B. Searching for new ways to integrate supply chain management activities
C. Establishing more frequent contact with members of your supply chain
D. Involving all members of your firm's supply chain in your product/service/marketing plan
E. Extending your supply chain to include members beyond immediate suppliers and customers

\section{Customer Value (CV)}
A. Successful resolution of customer complaints
B. Determination of future customer expectations
C. Making it easier for customers to seek assistance
D. Employing a customer satisfaction measurement system
E. Determination of key factors for improving customer satisfaction
F. Understanding how your customers use your products and services
G. Employing routine follow-up procedures for customer inquiries or complaints
H. Interacting with customers to set reliability, responsiveness and other standards

\section{Supplier Value (SV)}
A. Scope of resources under the control of your suppliers
B. Efforts of your suppliers in promoting JIT principles
C. Willingness of your suppliers to share confidential information
D. Willingness of suppliers to integrate with your supply chain
E. Emphasizing quality instead of price in the selection of suppliers
F. Commitment of suppliers to continuous improvement in your products and processes

\section{Internal Process Value (IPV)}
A. Use of operations practices for reducing lot sizes
B. Use of operations practices for reducing setup times
C. Use of operations practices for reducing the number of suppliers
D. Use of operations practices for ensuring buying from suppliers on a JIT basis
E. Use of operations practices for increasing the delivery frequencies
F. Use of operations practices for reducing the levels of inventory

\section{Firm Performance (PERF)}
A. Market share
B. Return on assets
C. Overall competitive position
D. Overall customer service levels 